\title{
Recent advances in "universal" influenza virus antibodies: the rise of a hidden trimeric interface in hemagglutinin globular head
}

\author{
Yulu Wang, Dan Hu, Yanling Wu (凶), Tianlei Ying (凶) \\ MOE/NHC/CAMS Key Laboratory of Medical Molecular Virology, School of Basic Medical Sciences, Shanghai Medical College, Fudan \\ University, Shanghai 200032, China \\ (C) Higher Education Press and Springer-Verlag GmbH Germany, part of Springer Nature 2020
}

\begin{abstract}
Influenza causes seasonal outbreaks yearly and unpredictable pandemics with high morbidity and mortality rates. Despite significant efforts to address influenza, it remains a major threat to human public health. This issue is partially due to the lack of antiviral drugs with potent antiviral activity and broad reactivity against all influenza virus strains and the rapid emergence of drug-resistant variants. Moreover, designing a universal influenza vaccine that is sufficiently immunogenic to induce universal antibodies is difficult. Some novel epitopes hidden in the hemagglutinin (HA) trimeric interface have been discovered recently, and a number of antibodies targeting these epitopes have been found to be capable of neutralizing a broad range of influenza isolates. These findings may have important implications for the development of universal influenza vaccines and antiviral drugs. In this review, we focused on the antibodies targeting these newly discovered epitopes in the HA domain of the influenza virus to promote the development of universal anti-influenza antibodies or vaccines and extend the discovery to other viruses with similar conformational changes in envelope proteins.
\end{abstract}

Keywords influenza virus; neutralizing antibody; hemagglutinin; globular head region; trimeric interface

\section{Introduction}

Influenza virus, a member of the Orthomyxoviridae family of viruses, is an enveloped virus with a negative-sense single-stranded RNA genome [1]. Influenza viruses can be classified according to the diversity of the surface proteins hemagglutinin (HA) and neuraminidase (NA) [2]. Currently, four types of influenza viruses have been identified: A, B, C, and D types [3]. Influenza A and B viruses are the most dominant among all types, and they circulate, disseminate, and cause seasonal influenza epidemics [4], which may lead to high mortality and morbidity rates in vulnerable populations (https://www.who.int/news-room/ fact-sheets/detail/influenza-(seasonal)). The World Health Organization has identified $18 \mathrm{HA}$ and 11 NA types in influenza A viruses. They can be further classified into two separate groups on the basis of HA type: group 1, which includes $H(1,2,5,6,8,9,11,12,13,16,17$, and 18); and group 2, which includes $\mathrm{H}(3,4,7,10,14$, and 15). Each

Received July 24, 2019; accepted March 4, 2020

Correspondence: Tianlei Ying, tlying@fudan.edu.cn; Yanling Wu, yanlingwu@fudan.edu.cn group has many subtypes that can infect humans, pigs, sea mammals, and birds $[5,6]$.

Influenza viruses have high mutation rates, which cause resistance to existing drugs; in addition, the development of "universal" protective antibodies and universal vaccine candidates to induce such antibodies is limited by the diversity and rapid evolution of influenza viruses [7]. Some avian influenza viruses, such as H5N1 [8], H7N9 [9,10], and H10N8 [11], can infect humans. In 1996, the H5N1 virus, which was isolated from a domestic goose, infected humans and caused 18 influenza cases and 6 deaths. Outbreaks of human infection were reported from 1998 to 2003; for example, H5N1 was reported in Hong Kong, China, H9N2 [12] was reported in Guangdong, China, and H7N7 [13] was reported in the Netherlands. In 2013, a new H7N9 avian influenza virus emerged in China and infected about 1500 individuals (http://www.who.int/ csr/don/01-may-2017-ah7n9-china/en/). The spread of the virus from one species to another is a severe risk factor to human health. The diversity and rapid evolution of influenza viruses are also serious problems that limit the development of "universal" protective antibodies and universal vaccine candidates to induce antibodies [14]. Furthermore, some highly conserved epitopes in the HA 
might have low immunogenicity, and they cannot easily induce antibody response. Thus, the key difficulty may be the development of new strategies to strengthen specific immunization and improve specific antibody selection. $\mathrm{Yu}$ et al. isolated $\mathrm{mAb} \mathrm{m} 826$ as a novel epitope in the HA trimeric interface that exerted highly therapeutic effects on mice with a lethal challenge of H7N9 [15]. This interface was previously considered to be hidden but can be exposed according to the recently proposed HA "breathing" theory [16]. Consequently, panels of broadly neutralizing antibodies targeting these epitopes were identified [16-18]. In the present work, we review the recent progress on these novel "universal" antibodies and discuss the potential implications of existing studies on influenza drug and vaccine development.

\section{Targets of influenza virus antibodies}

Influenza viruses primarily consist of eight gene segments, which encode ten identified proteins (Fig. 1). Among these proteins, three surface proteins, namely, HA, NA, and M2 (Fig. 1), are the most dominant and could be "observed" by the humoral immune system. Therefore, almost all antibodies that are known to inhibit viral proliferation target these proteins.

M2 is the influenza virus surface protein that acts as a proton channel at low $\mathrm{pH}$, following the uncoating of the viral ribonucleoprotein complex from the endosome to the cytoplasm [19,20]. However, antibodies against M2 are not neutralizing and generally do not confer protection by promoting effector functions on the basis of their Fc regions [21]. Furthermore, the antibody responses toward M2 are typically weak and/or transient after natural influenza infections in humans $[22,23]$. NA, another viral surface protein, acts as a receptor-destroying enzyme and removes sialic acid residues from the surface of infected cells to release and spread budding virions [24]. Although NA has lower variability than HA, it also undergoes a certain degree of antigenic drift, which may affect the intensity of NA antibody response to viruses or vaccines. The HA protein facilitates viral infection into host cells and

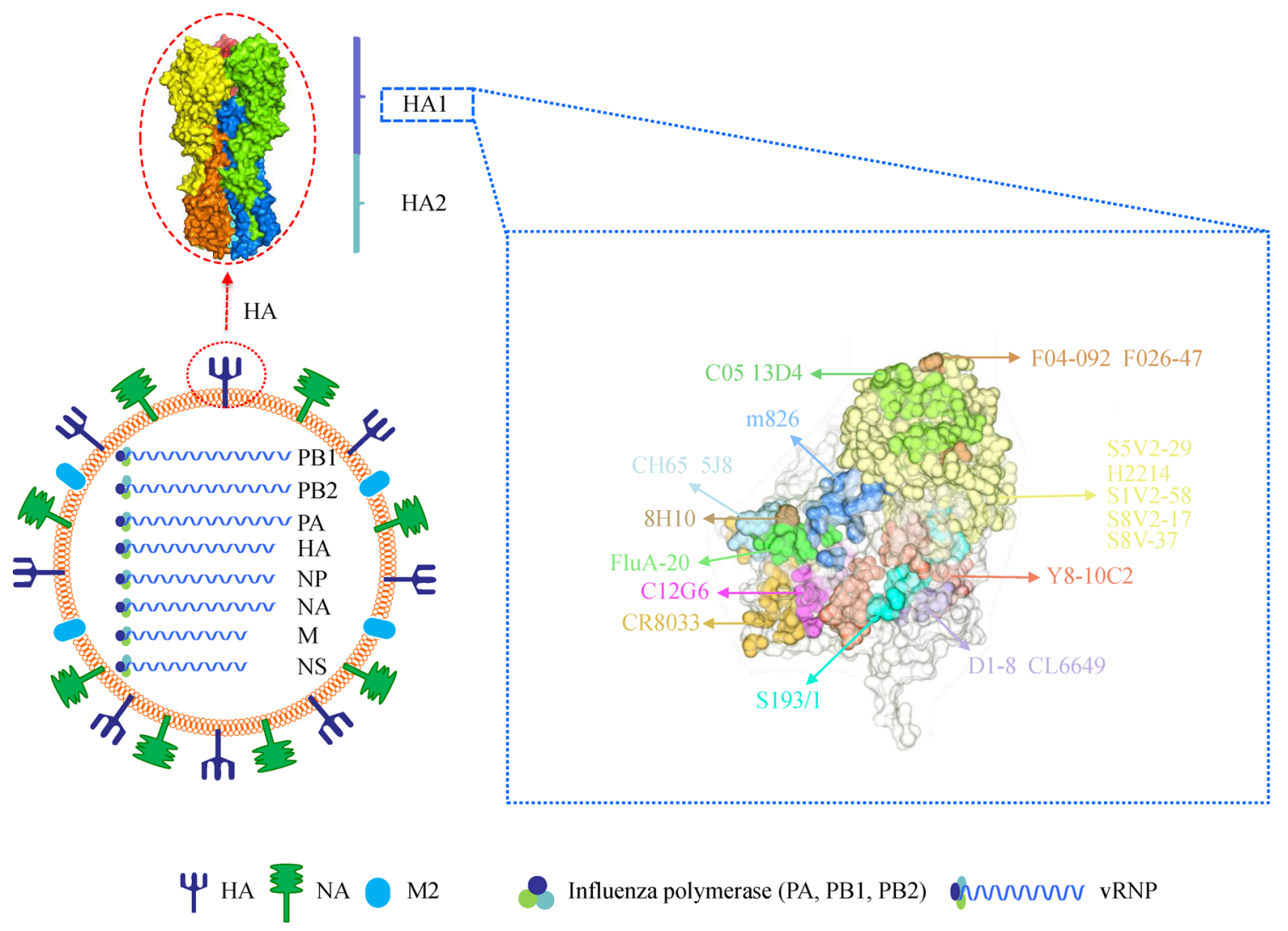

Fig. 1 Overview of influenza virus structure and epitopes recognized by neutralizing antibodies in the HA1 domain. The genomes of the influenza virus comprise eight gene segments, including polymerase basic 1 (PB1), polymerase basic 2 (PB2), polymerase acidic (PA), nucleoprotein (NP), matrix (M), nonstructural (NS), HA, and NA. The dominant glycoprotein on the viral surface, HA, mediates receptor binding, and membrane fusion is divided into HA1 and HA2. HA1 is the main target of neutralizing antibodies and antibody binding sites in the HA1 domain (indicated by different colors). 
influences the humoral immune response by shielding receptor binding sites (RBSs) and the process of antigenic drift. The antibodies targeting HA could directly neutralize viruses or stimulate the effector functions to eliminate infected host cells [25]. An analysis of blood samples collected from influenza virus-infected or immunized individuals shows that most broadly neutralizing antibodies target HA [26-30]. Therefore, the present work mainly focuses on the antibodies that target the highly conserved regions of HA.

\section{Influenza virus HA protein: structure and function}

HA, a type 1 glycoprotein on the virus surface, forms a homotrimer that measures approximately $220 \mathrm{kDa}$ and is responsible for the virus binding to the host cell receptors. The mature influenza HA monomer consists of two subunits [31], namely, HA1 and HA2 (Fig. 1); these subunits are connected by disulfide bonds and functions differently [32-34]. The HA1 region contains a highly antigenic domain, and the HA2 region is the conservative membrane fusion domain that aids viral and cell membrane fusion within the endosome.

The HA structure is metastable and changes dynamically through $\mathrm{pH}$ adjustment [35] because $\mathrm{pH}$ influences the neutral $\mathrm{pH}$ conformation of the protein found on the virus and induces viral and cell membrane fusion. During influenza infection, HA aids the influenza virus in binding to the host cell membrane via an HA/sialic acid interaction, which allows the internalization of viral particles via endocytosis. The HA protein is cleaved enzymatically into the N-terminal HA1 polypeptides with a distal domain of globular shape and C-terminal HA2 polypeptides with part of the HA1 polypeptide during endocytosis. Within the low $\mathrm{pH}$ (5-6) environment of the endosome, HA2 undergoes structural rearrangements, and the viral envelope fuses with host endosomal membranes, thereby allowing the virus to be internalized and the viral RNA to be released within the host cell [36].

HA is an appropriate target for inhibiting influenza viruses [37] because it is not only the most abundant protein antigen on the viral surface but also a critical factor that facilitates viral infection. The HA domain is diverse; however, almost all HA domains, except the newly identified $\mathrm{H} 17$ and H18 HAs from bats, play the same role of aiding the binding of viruses to host cells and inducing the fusion of viruses and host cell membranes [38-41]. Thus, blocking the RBS or inhibiting the process of HA maturation and membrane fusion are two suitable ways to prevent influenza viral infection. The two types of influenza viral antibodies target the globular head (HA1) or stem (HA2) regions of HA [29].

\section{Conventional anti-HA antibodies: what we have learned so far}

Most neutralizing antibodies against influenza viruses are directed to the conformational epitopes on HA, particularly the globular head domain. A vast number of influenzaneutralizing antibodies against the HA globular domain are strain-specific and can efficiently prevent infection by blocking the HA-mediated attachment to cells. Examples of such antibodies include the H1-specific antibody 5J8, the $\mathrm{H} 2$-specific antibody $8 \mathrm{M} 2$, the H5-specific antibody 13D4, and the H7-specific antibody H7.5 [18,42-44], whose binding sites are close to or overlap with RBSs. In 2018, an H1-specific antibody CL6649 identified another conserved site on the HA head side of the H1 subtype; this site is called a "lateral patch" [45]. However, strain-specific antibodies bind to epitopes with high mutation rates, thereby allowing antibody binding sites to change and escape from antibody-mediated neutralization.

Identifying the conserved sites in the variable head domain is difficult $[32,46]$, and only a few anti-HA head domain antibodies have been described as broadly neutralizing antibodies. In 2009, mAb S139/1 was isolated from immunized mice with $\mathrm{H} 3$ viruses, and it exhibited neutralization activity against the $\mathrm{H} 1, \mathrm{H} 2$, and $\mathrm{H} 3$ strains. Its epitope is located in the antigen site B near the RBS [47]. A human monoclonal antibody called $\mathrm{CH} 65$ was obtained by isolating it from a subject immunized with the 2007 trivalent influenza vaccine, and it neutralized 30 out of 36 H1N1 strains. An analysis of the CH65-H1N1 complex showed that $\mathrm{CH} 65$ binds to the receptor binding pocket on HA1 through HCDR3, mimicking the physiologic interaction between sialic acid and HA [48]. Using phage antibody libraries from a human donor, Ekiert et al. isolated $\mathrm{mAb}(\mathrm{C} 05)$, which binds directly to the RBS on HA and neutralizes strains from multiple subtypes of the influenza A virus, including $\mathrm{H} 1, \mathrm{H} 2$, and $\mathrm{H} 3$ [49]. In addition, some broadly neutralizing antibodies whose epitopes are far from the RBS have been described. Two anti-head mAbs, F045-092 and F026-427, were identified from human B lymphocytes by screening with the H3N2 virus; these antibodies showed activity against H1N1, $\mathrm{H} 3 \mathrm{~N} 2$, and $\mathrm{H} 5 \mathrm{~N} 1$ viruses [50]. D1-8 is a human mAb targeting the antigenic site $\mathrm{D}$ and exhibits potent, broadly neutralizing activity across antigenically diverse influenza H3 subtype viruses [26]. Moreover, 429B01 is particularly broad and binds to groups 1 and 2 viruses [51]. Antibodies CR8033 and CR8071 recognize a distinct conserved epitope in the HA head domain of the influenza B virus, and they have broad protection against influenza $\mathrm{A}$ and $\mathrm{B}$ viruses [52]. C12G6 targets a conserved epitope that overlaps with the RBS in the HA region of the influenza $\mathrm{B}$ virus and therefore protects against influenza $B$ infection [53]. These previous studies indicated that most anti-HA 
head regions neutralizing antibodies only offer a narrow line of protection and do not neutralize all influenza subtypes due to the high level of sequence diversity in the HA heads between subtypes, as well as the incorporation of large amounts of glycans in this region.

Broadly neutralizing antibodies usually target the stem region of HA due to the low variability of the stem domain. Such stem-targeted bnAbs recognize the highly conserved regions of the stem and inhibit the conformational changes necessary for viral fusion. Therefore, these bnAbs, e.g., CR9114 and MEDI8852, have more extensive heterotypeneutralizing activity compared with most head-targeted antibodies; some can even target almost all HA types and groups [54-57]. Recently, panels of neutralizing stemdirected human-derived bnAbs have been reported. A human monoclonal antibody called CR9114 recognizes a conserved epitope in the HA stem and protects against lethal challenges with the influenza A and B viruses [52]. Neutralizing antibodies CR6261, F10, or 70-1F02 against group 1 influenza types target highly conserved pocket regions in the stem of HA using only heavy chains due to a phenylalanine in position 54 at the HCDR2 region unique to the $\mathrm{VH}_{1-69}$ gene $[55,58]$. Prior studies have shown that these antibodies can be elicited by vaccination [59-62]. However, $\mathrm{VH}_{1-69}$-derived antibodies generally do not neutralize groups 1 and 2 strains of influenza $A$, and only CR9114 can neutralize both groups [63]. By contrast, group 2-specific antibodies, such as CR8020, bind to epitopes closer to virus membranes [64]. As the most extensive heterotype-neutralizing antibodies that recognize both groups of HAs, mAb FI6 and FI6V3 can bind to conserved epitopes in the F subdomain [65]. Moreover, bnAbs specific for the HA stem region usually require Fc $\gamma R$-mediated effector functions, which act via the interactions of the $\mathrm{Fc}$ region of the antibodies with $\mathrm{Fc \gamma R}$ receptors, to protect against influenza virus in vivo and kill virus-infected target cells by attracting immune cells, such as NK cells, macrophages, and neutrophils [66]. However, the humoral response of the HA stem region is generally weaker than that of the more immunogenic HA trimer globular head region [17], leading to the vast generation of anti-HA globular head domain antibodies during infection with an influenza virus. Therefore, developing a universal vaccine that promotes the generation of anti-stem antibodies or using anti-stem antibodies via passive immunization in infected individuals is difficult.

Designing a universal influenza vaccine that is sufficiently immunogenic to induce universal antibodies capable of neutralizing a broad range of influenza isolates is difficult partly because of the lack of highly conserved epitopes in the HA globular head region $[16,23]$. With the advances in antibody discovery-related technologies, a growing number of antibodies are being identified, and some of them target critical functional regions that are not highly sensitive to antigenic drifts in the HA domain
$[67,68]$. Particular attention has been paid to some novel epitopes hidden in the influenza trimeric HA head interface $[69,70]$. These studies have rekindled the interest in the development of "next-generation" universal influenza virus antibodies and corresponding vaccine immunogens.

\section{Recent advances in anti-HA antibodies}

In the past decade, extensive efforts have been made to identify the extremely conserved epitopes and corresponding universal influenza antibodies [17,68,71,72]. Several strategies focused on the rational design of HA antigens that could expose conserved epitopes to generate bnAbs [73-76]. The glycosylation in the HA domain is involved in the antigenic drift of influenza viruses; influenza viruses have been found to introduce or remove glycans to change the viral structure and shield the sites near the RBS on its surface to reduce or evade host immune response [77-79]. A number of studies engineered glycans to expose the hidden conserved epitopes in the HA domain. For instance, one article reported that modifying glycosylation sites in the HA stem region leads to unmasked sites by N-glycans that elicit effective broadly neutralizing antibodies [80]. Such studies confirmed the potential role of engineering in changing the immunogenicity of antigens and exposing conserved sites, which are the key to induce broadly neutralizing antibodies $[76,81,82]$.

In a recent research article, the authors engineered a number of hyperglycosylated versions of HA and used them to immunize animals [76]. In their work, the glycans changed the initially diverse antibody response into a focused one. Three monoclonal antibodies were identified and designated as 8H10, FL-1056, and FL-1066. The structural studies showed that the binding sites of the three antibodies belonged to the HA head domain in the same epitope that is ordinarily occluded on a prefusion structure and hidden in the trimeric HA head interface. With the introduction of non-native putative $\mathrm{N}$-linked glycosylation sites, such occluded and highly conserved epitopes were exposed in the glycosylated HA molecules; such condition allowed for the broad (but not complete) antibody $\mathrm{mAb}$ $8 \mathrm{H} 10$ to recognize all of the identified $\mathrm{H} 3$ types and a representative $\mathrm{H} 4$ type $[16,76]$. The article proposed that hyperglycosylated HA could block some epitopes from exposure to occluded epitopes and elicit broadly protective responses.

A class of anti-influenza virus antibodies targeting the interface of HA trimer has been identified. In 1988, a monoclonal antibody Y8-10C2 was described. Y8-10C2 recognized an epitope located at the interface of adjacent subunits and exposed to antibody binding only after acid treatment of HA [83-85]. In 2016, a panel of H1 + H3 cross-reactive antibodies, discovered by Georgiou's group 
and identified in multiple donors who received the trivalent seasonal influenza vaccine, all bound to a highly conserved epitope on monomeric HA located on the RBS but occluded in the intact HA trimer. Moreover, these antibodies conferred prophylactic and therapeutic protection against challenge by group 1 and group 2 strains despite their complete lack of neutralization activity in vitro [86]. However, the precise mechanism for protection remains under investigation. Recently, some novel epitopes that are targeted by therapeutic antibodies but are difficult to be accessed in intact trimeric HA have been identified. The H7N9-specifc antibody, m826, is isolated from a large phage-displayed library and binds to HA1 with subnanomolar affinity. Interestingly, m826 exhibits $\mathrm{pH}$-sensitive binding to trimeric HA. It binds to trimeric HA with subnanomolar affinity at $\mathrm{pH} 5.0$; binding at $\mathrm{pH}$ 7.4 is about 10 -fold weaker. The crystal structure of Fab m826 in the complex with the H7N9 HA1 fragment shows that $\mathrm{m} 826$ binds to a unique epitope on H7 HA that is buried in the trimeric structure. The mechanism of action could be deciphered by the "breathing" of the HA protomers [15]. Turner et al. also found this mechanism by observing the process of HA binding to a potent influenza $\mathrm{H} 7 \mathrm{HA}$ head-directed $\mathrm{mAb}$ through cryoelectron microscopy. The epitope of the antibody is not solvent and accessible in the compact prefusion conformation but is transiently exposed during "breathing" [18]. In 2019, a study discovered a naturally occurring human monoclonal antibody, FluA-20, which can protect against almost all influenza types [87]. Structural studies revealed the novel epitopes of FluA-20 that are extremely well conserved on the non-RBS side across diverse types. The novel epitopes are positioned in the 220 loop and the adjacent 90 loop, which is usually buried in the native HA trimer (Fig. 2).

These findings suggest that the HA trimer is dynamic [88-90] and that the interface can be opened, perhaps transiently or partially, to expose conserved sites. The "breathing" of the interface of the HA head domain has also been reported $[16-18,87]$. HA0 is the HA precursor protein. HA is assembled into a trimer by protein folding in the endoplasmic reticulum and is then transported to the cell surface for maturation [91,92]. HA cleavage is required for the infectivity of influenza viruses $[93,94]$. A previous study demonstrated that HA cleavage alters the HA trimer dynamics, influences the presentation of the
A

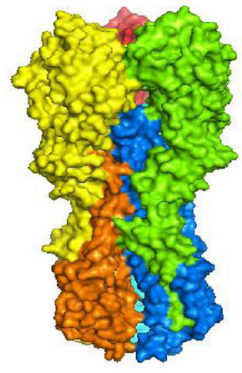

Influenza HA
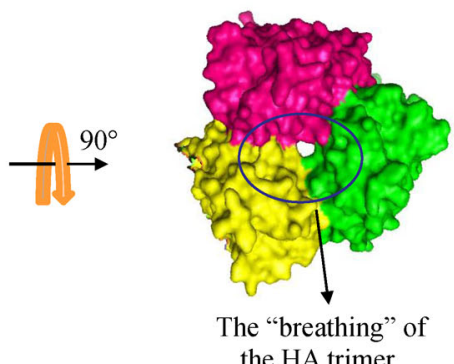

the HA trimer

B

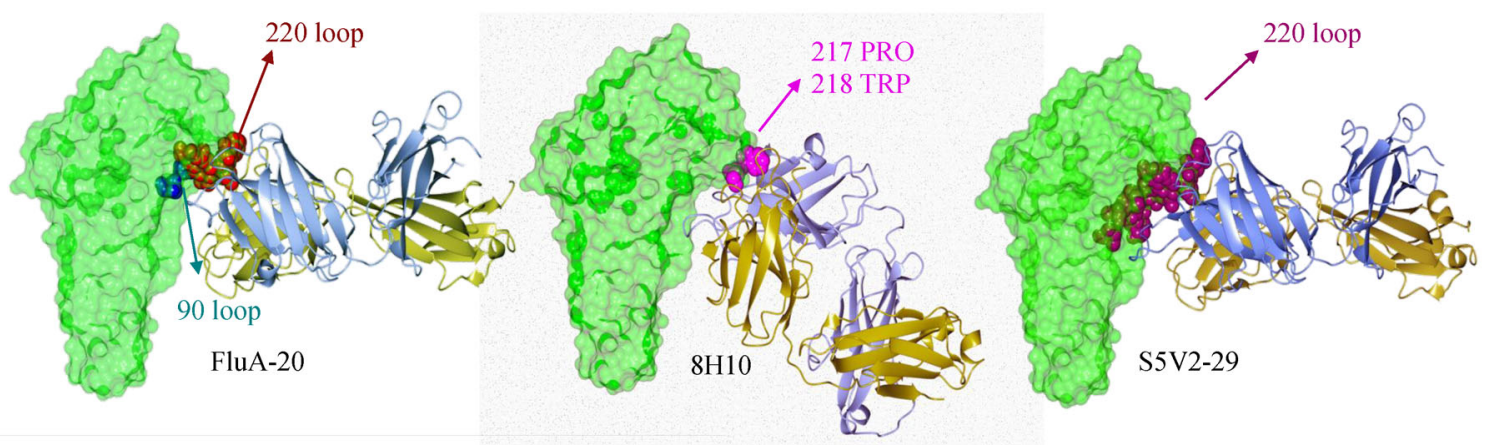

Fig. 2 HA interface is the critical binding site for neutralizing antibodies. (A) Trimeric HA structure seen from the side and top in space filling. The HA trimer is dynamic, and the partially open structure is observed after a change in conformation, which resembles "breathing." (B) The epitopes are presented by the representative structure of targeting HA-interfaced antibody-HA complexes (FluA-20, $8 \mathrm{H} 10$, and S5V2-29). The "breathing" process of the HA trimer exposes a concealed epitope, which can be recognized by protective and well-conserved antibodies. The 220 loop is targeted by antibodies FluA-20 and H3-S5V2-29 partially for 8H10. 
FluA-20 epitope, and reduces antibody function. Exposure of HA residues allowed these residues to be recognized by FluA-20, thereby confirming the presence of previously unnoticed dynamic features of the HA trimer [87].

Another study reported the isolation of S5V2-29, H2214, S1V2-58, S8V2-17, and S8V2-37 from the human donors and identified epitope $\mathrm{S} 5-\mathrm{C} 1$ that is extremely conserved on the non-RBS hidden HA globular head region and covers residues between 91 and 206 and between 219 and 230 [17]. All these five human antibodies own the collective breadth covering group 1 and almost all of group 2 HA (H1, H2, H3, H5, H7, H9, and H14). S5C1-lineage B cell receptors (BCRs) have a similar gene composition. The complex structure of the antibodies bound to monomeric HA has been described [17]. At neutral $\mathrm{pH}$, the epitope on the HA trimer interface recognized by antibodies is normally hidden in the shield to prevent access by the antibody or BCR [88]. However, the HA trimer could undergo conformational changes dynamically with $\mathrm{pH}$ adjustment. The HA trimer is more dynamic in the floating $\mathrm{pH}$ environment, and if the transiently exposed epitopes encounter B cells, the BCRs can recognize the virus, thus allowing for the induction of the primary immune response against the influenza virus $[17,95]$. Although BCRs or antibodies can bind to virus particles, the transient nature of the exposure site results in a binding rate lower than that for fully exposed epitopes. Failure to prevent the initial infection of cells in vitro indicates that the HA trimer's conformational fluctuations expose the epitope at the interface to a certain extent $[17,91,96]$. Thus, only a small fraction of the head interface epitopes could be exposed [97-99]. These studies also showed that although most BCRs are specific for HA epitopes, only a minority of these broadly cross-reactive memory B cells recognize RBS epitopes. Instead, numerous cross-reactive memory $\mathrm{B}$ cells recognize nonRBS epitopes. Therefore, systematic investigations into HA head epitopes that have not been identified to date are important. Such epitopes may prove to be immunogenic components of a broadly protective influenza virus drugs and vaccines.

In summary, three independent groups have reported similar results in the identification of important epitopes on the non-RBS HA globular head region, as well as the related universal antibodies that are protective against many influenza virus types $[17,76,87]$. All antibodies bind to a hidden interface in the HA trimer and have no neutralizing activities, but they protect mice against challenge with influenza viruses via strongly $\mathrm{Fc}$-dependent mechanisms or disruption of the HA trimer. The characteristics of some of these antibodies are briefly summarized in Table 1.

The new protective epitopes recognized by the antibodies are transiently or partially exposed under certain conditions; this property is reminiscent of the $\mathrm{pH}$-mediated reversible "breathing" of HA that has been supported by recent HA kinetic studies $[16,88]$. The viral surface envelope protein is dynamic and always changing, thereby resembling "breathing" and showing that exposed cryptic epitopes can be targeted by protective antibodies. This "breathing" phenomenon has also been observed in envelope glycoproteins from other viruses, e.g., MERSCoV, dengue virus, Zika virus, and HIV [100-103]. Moreover, a number of antibodies targeting possibly hidden conserved epitopes in these viruses have been identified in humans. Hence, these epitopes are promising candidates for developing "universal" vaccines.

\section{Summary and perspectives}

The discovery of broadly neutralizing antibodies targeting highly conserved epitopes has renewed the hope of developing universal influenza drugs and vaccines. Recent data have shown that antibody and memory B cell responses against the variable epitopes of the HA head are much higher than the responses of antibodies and memory B cells directed against the conserved HA stem cell region $[17,70,104]$. However, the most widely reported anti-HA head region antibodies do not have broadly neutralizing activity and only offer a narrow line of protection due to the high level of sequence diversity and incorporation of large amounts of glycans in this region.

The recent studies reviewed herein provided comprehensive analyses and showed that novel epitopes hidden in the influenza trimeric HA head interface, which are conserved across most influenza groups, may not be affected by the immune pressure driving the antigenic drift of viruses. Therefore, such "breathing" interface might represent an ideal immunogenic candidate and should be considered as a potential site to be used in the development of drugs and vaccines against influenza virus infections.

Unlike anti-stem antibodies, most anti-HA head antibodies do not rely on ADCC activity, and they exhibit exceptional breadth and potency even in the Fab (antibody without the Fc domain) format [105]. This finding suggests the potential to develop small antibody constructs, such as single domain antibodies [106], which could more easily access the "breathing" subdomain or other hidden epitopes than large-sized IgG antibodies. With the establishment and further development of the HA "breathing" theory, an increasing number of antibodies targeting the hidden trimeric interface are expected to be discovered in the near future.

\section{Acknowledgements}

This work was supported by the National Natural Science Foundation of China (Nos. 81822027 and 81630090), the National Key R\&D Program of China (No. 2019YFA0904400), the National 
Table 1 Monoclonal antibodies specific for HA stalk and trimeric interface

\begin{tabular}{|c|c|c|c|c|c|c|}
\hline & \multirow{2}{*}{ Antibody } & \multirow{2}{*}{ Year } & \multirow{2}{*}{ Epitope } & \multicolumn{2}{|c|}{ Activity } & \multirow{2}{*}{ Phase } \\
\hline & & & & In vitro & In vivo & \\
\hline \multirow[t]{3}{*}{ Anti-stalk } & CR6261 [55] & 2008 & $\begin{array}{l}\text { A highly conserved } \\
\text { helical region in the } \\
\text { membrane-proximal } \\
\text { stem of HA1 and } \\
\text { HA2 }\end{array}$ & $\begin{array}{l}\text { Neutralization group } 1 \\
\text { (H1, H2, H5, H6, H8, } \\
\text { H9, H11, H12, H13, } \\
\text { H16) }\end{array}$ & $\begin{array}{l}\text { In mice: } \\
\text { H2N2-1.7mg/kg-100\% } \\
\text { survival rate; } \\
\text { H2N3-1.7mg/kg-100\% } \\
\text { survival rate } \\
\text { In ferret: } \\
\text { H5N1-30mg/kg-100\% } \\
\text { survival rate }\end{array}$ & Phase 2 \\
\hline & CR8020 [64] & 2011 & $\begin{array}{l}\text { A highly conserved } \\
\text { epitope in the HA stalk } \\
\text { close to the virus } \\
\text { membrane }\end{array}$ & $\begin{array}{l}\text { Neutralization group } 2 \\
\text { (H3, H4, H7, H10, H14, } \\
\text { H15) }\end{array}$ & $\begin{array}{l}\text { Mice challenges } \\
\text { H3N3-3mg/kg-100\% } \\
\text { survival rate; } \\
\text { H7N7-3mg/kg-100\% } \\
\text { survival rate }\end{array}$ & Phase 2 \\
\hline & MEDI8852 [57] & 2016 & $\begin{array}{l}\text { A highly conserved } \\
\text { epitope encompassing } \\
\text { a hydrophobic groove } \\
\text { in the fusion domain } \\
\text { and a large portion of } \\
\text { the fusion peptide }\end{array}$ & $\begin{array}{c}\text { Neutralization group } 1 \\
\text { (H1, H2, H5, H6, H9) } \\
\text { and group } 2(\mathrm{H} 3, \mathrm{H} 7)\end{array}$ & $\begin{array}{l}\text { Mice and ferret challenge } \\
\text { studies } \\
\text { In mice: } \\
\text { H5N1-10 mg/kg-100\% } \\
\text { survival rate; } \\
\text { H7N9-10 mg/kg-100\% } \\
\text { survival rate } \\
\text { In ferret: } \\
\text { H5N1-12.5 mg/kg-86\% } \\
\text { survival rate }\end{array}$ & Phase $1 b / 2 a$ \\
\hline \multirow[t]{2}{*}{$\begin{array}{l}\text { Anti-trimeric } \\
\text { interface }\end{array}$} & FluA-20 [87] & 2019 & $\begin{array}{l}\text { An exceedingly conserved } \\
\text { protective determinant in } \\
\text { the influenza HA head } \\
\text { domain trimer interface }\end{array}$ & $\begin{array}{l}\text { No neutralization but } \\
\text { mediates ADCC against } \\
\text { group } 1(\mathrm{H} 1, \mathrm{H} 2, \mathrm{H} 5, \mathrm{H} 6, \\
\mathrm{H} 8, \mathrm{H} 9, \mathrm{H} 11, \mathrm{H} 12, \mathrm{H} 16) \\
\text { and group } 2(\mathrm{H} 3, \mathrm{H} 4, \mathrm{H} 7, \\
\mathrm{H} 10, \mathrm{H} 14, \mathrm{H} 15)\end{array}$ & $\begin{array}{l}\text { Mice challenge studies: } \\
\text { H1N1-10 mg/kg-100\% } \\
\text { survival rate; } \\
\text { H3N2-10 mg/kg-80\% } \\
\text { survival rate; } \\
\text { H5N1-10 mg/kg-100\% } \\
\text { survival rate }\end{array}$ & Preclinical \\
\hline & S5V2-29 [17] & 2019 & $\begin{array}{l}\text { The epitope, occluded in } \\
\text { the pre-fusion form of } \\
\text { HA, is at the contact } \\
\text { surface between HA } \\
\text { head domains }\end{array}$ & $\begin{array}{l}\text { No neutralization but the } \\
\text { Fc-dependent protection } \\
\text { against group } 1 \text { (H1, H2, } \\
\text { H5, H6, H8, H9, H11, } \\
\text { H12, H13, H16) and } \\
\text { group } 2(\mathrm{H} 3, \mathrm{H} 4, \mathrm{H} 7 \text {, } \\
\text { H10, H14, H15) }\end{array}$ & $\begin{array}{l}\text { Mice challenge studies: } \\
\text { H3N2-100 } \mu \mathrm{g}-100 \% \\
\text { survival rate; } \\
\text { H1N1-100 } \mu \mathrm{g}-90 \% \\
\text { survival rate }\end{array}$ & Preclinical \\
\hline
\end{tabular}

Science and Technology Major Projects of Infectious Disease funds (No. 2018ZX10301403), and the grant from the Chinese Academy of Medical Sciences (No. 2019PT350002).

\section{Compliance with ethics guidelines}

Yulu Wang, Dan $\mathrm{Hu}$, Yanling Wu, and Tianlei Ying declare that they have no conflict of interest. This manuscript is a review article and does not involve a research protocol requiring approval by the relevant institutional review board or ethics committee.

\section{References}

1. Zhilinskaia IN, Tets VV, Golubev DB. Genome structure of influenza virus. Vopr Virusol 1978; (4): 387-394 (in Russian)

2. Rudneva IA, Sklyanskaya EI, Barulina OS, Yamnikova SS,
Kovaleva VP, Tsvetkova IV, Kaverin NV. Phenotypic expression of HA-NA combinations in human-avian influenza A virus reassortants. Arch Virol 1996; 141(6): 1091-1099

3. To J, Torres J. Viroporins in the influenza virus. Cells 2019; 8(7): E654

4. Zambon MC. Epidemiology and pathogenesis of influenza. J Antimicrob Chemother 1999; 44 Suppl B: 3-9

5. Krammer F. Emerging influenza viruses and the prospect of a universal influenza virus vaccine. Biotechnol J 2015; 10(5): 690701

6. Pleschka S. Overview of influenza viruses. In: Swine Influenza. Part of the Current Topics in Microbiology and Immunology book series (CT MICROBIOLOGY, volume 370). Springer: 2013. 1-20

7. Grist NR. Epidemiology and pathogenesis of influenza. BMJ 1970; 3(5718): 344-345

8. Saw TA, et al. Isolation of avian influenza A (H5N1) viruses from humans - Hong Kong, May-December 1997 (Reprinted from MMWR, vol 46, pg 1204-1207, 1997). JAMA 1998; 279(4): 263- 
264

9. Tang RB, Chen HL. An overview of the recent outbreaks of the avian-origin influenza A (H7N9) virus in the human. J Chin Med Assoc 2013; 76(5): 245-248

10. Ding H, Xie L, Sun Z, Kao QJ, Huang RJ, Yang XH, Huang CP, Wen YY, Pan JC, Pu XY, Jin T, Zhou XH, Zheng L, Li J, Wang FJ. Epidemiologic characterization of 30 confirmed cases of human infection with avian influenza A(H7N9) virus in Hangzhou, China. BMC Infect Dis 2014; 14(1): 175

11. Tan W, Li M, Xie ZX. An overview of avian influenza A H10N8 subtype viruses. Pak Vet J 2016; 36(3): 251-257

12. Guo Y, Li J, Cheng X. Discovery of men infected by avian influenza A (H9N2) virus. Chin J Exp Clin Viro (Zhonghua Shi Yan He Lin Chuang Bing Du Xue Za Zhi) 1999; 13(2): 105-108 (in Chinese)

13. Stegeman A, Bouma A, Elbers AR, de Jong MC, Nodelijk G, de Klerk F, Koch G, van Boven M. Avian influenza A virus (H7N7) epidemic in the Netherlands in 2003: course of the epidemic and effectiveness of control measures. J Infect Dis 2004; 190(12): 2088-2095

14. Sautto GA, Kirchenbaum GA, Ross TM. Towards a universal influenza vaccine: different approaches for one goal. Virol J 2018; 15(1): 17

15. Yu F, Song H, Wu Y, Chang SY, Wang L, Li W, Hong B, Xia S, Wang C, Khurana S, Feng Y, Wang Y, Sun Z, He B, Hou D, Manischewitz J, King LR, Song Y, Min JY, Golding H, Ji X, Lu L, Jiang S, Dimitrov DS, Ying T. A potent germline-like human monoclonal antibody targets a $\mathrm{pH}$-sensitive epitope on H7N9 influenza hemagglutinin. Cell Host Microbe 2017; 22(4): 471-483. e5

16. Wu Y, Gao GF. "Breathing" hemagglutinin reveals cryptic epitopes for universal influenza vaccine design. Cell 2019; 177 (5): 1086-1088

17. Watanabe A, McCarthy KR, Kuraoka M, Schmidt AG, Adachi Y, Onodera T, Tonouchi K, Caradonna TM, Bajic G, Song S, McGee CE, Sempowski GD, Feng F, Urick P, Kepler TB, Takahashi Y, Harrison SC, Kelsoe G. Antibodies to a conserved influenza head interface epitope protect by an IgG subtype-dependent mechanism. Cell 2019; 177(5): 1124-1135.e16

18. Turner HL, Pallesen J, Lang S, Bangaru S, Urata S, Li S, Cottrell CA, Bowman CA, Crowe JE Jr, Wilson IA, Ward AB. Potent antiinfluenza $\mathrm{H} 7$ human monoclonal antibody induces separation of hemagglutinin receptor-binding head domains. PLoS Biol 2019; 17(2): e3000139

19. Pielak RM, Schnell JR, Chou JJ. Mechanism of drug inhibition and drug resistance of influenza A M2 channel. Proc Natl Acad Sci USA 2009; 106(18): 7379-7384

20. Chizhmakov IV, Geraghty FM, Ogden DC, Hayhurst A, Antoniou M, Hay AJ. Selective proton permeability and $\mathrm{pH}$ regulation of the influenza virus M2 channel expressed in mouse erythroleukaemia cells. J Physiol 1996; 494(2): 329-336

21. Saelens $X$. The role of matrix protein 2 ectodomain in the development of universal influenza vaccines. J Infect Dis 2019; 219(Supplement_1): S68-S74

22. Zhang X, Liu M, Liu C, Du J, Shi W, Sun E, Li H, Li J, Zhang Y. Vaccination with different M2e epitope densities confers partial protection against $\mathrm{H} 5 \mathrm{~N} 1$ influenza A virus challenge in chickens.
Intervirology 2011; 54(5): 290-299

23. Corti D, Cameroni E, Guarino B, Kallewaard NL, Zhu Q, Lanzavecchia A. Tackling influenza with broadly neutralizing antibodies. Curr Opin Virol 2017; 24: 60-69

24. Jones LV, Compans RW, Davis AR, Bos TJ, Nayak DP. Surface expression of influenza virus neuraminidase, an amino-terminally anchored viral membrane glycoprotein, in polarized epithelial cells. Mol Cell Biol 1985; 5(9): 2181-2189

25. Ohmit SE, Petrie JG, Cross RT, Johnson E, Monto AS. Influenza hemagglutination-inhibition antibody titer as a correlate of vaccine-induced protection. J Infect Dis 2011; 204(12): 1879-1885

26. Benjamin E, Wang W, McAuliffe JM, Palmer-Hill FJ, Kallewaard NL, Chen Z, Suzich JA, Blair WS, Jin H, Zhu Q. A broadly neutralizing human monoclonal antibody directed against a novel conserved epitope on the influenza virus H3 hemagglutinin globular head. J Virol 2014; 88(12): 6743-6750

27. Cho A, Wrammert J. Implications of broadly neutralizing antibodies in the development of a universal influenza vaccine. Curr Opin Virol 2016; 17: 110-115

28. Wu NC, Grande G, Turner HL, Ward AB, Xie J, Lerner RA, Wilson IA. In vitro evolution of an influenza broadly neutralizing antibody is modulated by hemagglutinin receptor specificity. Nat Commun 2017; 8(1): 15371

29. Laursen NS, Wilson IA. Broadly neutralizing antibodies against influenza viruses. Antiviral Res 2013; 98(3): 476-483

30. Hu W, Chen A, Miao Y, Xia S, Ling Z, Xu K, Wang T, Xu Y, Cui J, Wu H, Hu G, Tian L, Wang L, Shu Y, Ma X, Xu B, Zhang J, Lin $\mathrm{X}$, Bian C, Sun B. Fully human broadly neutralizing monoclonal antibodies against influenza A viruses generated from the memory B cells of a 2009 pandemic H1N1 influenza vaccine recipient. Virology 2013; 435(2): 320-328

31. Skehel JJ, Waterfield MD. Studies on the primary structure of the influenza virus hemagglutinin. Proc Natl Acad Sci USA 1975; 72 (1): 93-97

32. Russell $\mathrm{CJ}, \mathrm{Hu} \mathrm{M}$, Okda FA. Influenza hemagglutinin protein stability, activation, and pandemic risk. Trends Microbiol 2018; 26 (10): 841-853

33. Gamblin SJ, Skehel JJ. Influenza hemagglutinin and neuraminidase membrane glycoproteins. J Biol Chem 2010; 285(37): 2840328409

34. Skehel JJ, Wiley DC. Receptor binding and membrane fusion in virus entry: the influenza hemagglutinin. Annu Rev Biochem 2000; 69(1): 531-569

35. Garcia NK, Guttman M, Ebner JL, Lee KK. Dynamic changes during acid-induced activation of influenza hemagglutinin. Structure $2015 ;$ 23(4): 665-676

36. Gaudin Y, Ruigrok RW, Brunner J. Low-pH induced conformational changes in viral fusion proteins: implications for the fusion mechanism. J Gen Virol 1995; 76(Pt 7): 1541-1556

37. Zhang Y, Xu C, Zhang H, Liu GD, Xue C, Cao Y. Targeting hemagglutinin: approaches for broad protection against the influenza A virus. Viruses 2019; 11(5): E405

38. Lee PS, Wilson IA. Structural characterization of viral epitopes recognized by broadly cross-reactive antibodies. In: Oldstone M, Compans R. Influenza Pathogenesis and Control-Volume II. Current Topics in Microbiology and Immunology, vol 386. Springer, Cham: 2014. 323-341 
39. Sun X, Shi Y, Lu X, He J, Gao F, Yan J, Qi J, Gao GF. Bat-derived influenza hemagglutinin $\mathrm{H} 17$ does not bind canonical avian or human receptors and most likely uses a unique entry mechanism. Cell Rep 2013; 3(3): 769-778

40. Zhu X, Yu W, McBride R, Li Y, Chen LM, Donis RO, Tong S, Paulson JC, Wilson IA. Hemagglutinin homologue from H17N10 bat influenza virus exhibits divergent receptor-binding and $\mathrm{pH}$ dependent fusion activities. Proc Natl Acad Sci USA 2013; 110(4): 1458-1463

41. Tong S, Zhu X, Li Y, Shi M, Zhang J, Bourgeois M, Yang H, Chen X, Recuenco S, Gomez J, Chen LM, Johnson A, Tao Y, Dreyfus C, Yu W, McBride R, Carney PJ, Gilbert AT, Chang J, Guo Z, Davis CT, Paulson JC, Stevens J, Rupprecht CE, Holmes EC, Wilson IA, Donis RO. New world bats harbor diverse influenza A viruses. PLoS Pathog 2013; 9(10): e1003657

42. Krause JC, Tsibane T, Tumpey TM, Huffman CJ, Albrecht R, Blum DL, Ramos I, Fernandez-Sesma A, Edwards KM, GarcíaSastre A, Basler CF, Crowe JE Jr. Human monoclonal antibodies to pandemic 1957 H2N2 and pandemic 1968 H3N2 influenza viruses. J Virol 2012; 86(11): 6334-6340

43. Lee PS, Ohshima N, Stanfield RL, Yu W, Iba Y, Okuno Y, Kurosawa Y, Wilson IA. Receptor mimicry by antibody F045-092 facilitates universal binding to the $\mathrm{H} 3$ subtype of influenza virus. Nat Commun 2014; 5(1): 3614

44. Brandenburg B, Koudstaal W, Goudsmit J, Klaren V, Tang C, Bujny MV, Korse HJ, Kwaks T, Otterstrom JJ, Juraszek J, van Oijen AM, Vogels R, Friesen RH. Mechanisms of hemagglutinin targeted influenza virus neutralization. PLoS One 2013; 8(12): e80034

45. Raymond DD, Bajic G, Ferdman J, Suphaphiphat P, Settembre EC, Moody MA, Schmidt AG, Harrison SC. Conserved epitope on influenza-virus hemagglutinin head defined by a vaccine-induced antibody. Proc Natl Acad Sci USA 2018; 115(1): 168-173

46. Russier M, Yang G, Rehg JE, Wong SS, Mostafa HH, Fabrizio TP, Barman S, Krauss S, Webster RG, Webby RJ, Russell CJ. Molecular requirements for a pandemic influenza virus: an acidstable hemagglutinin protein. Proc Natl Acad Sci USA 2016; 113 (6): 1636-1641

47. Yoshida R, Igarashi M, Ozaki H, Kishida N, Tomabechi D, Kida H, Ito K, Takada A. Cross-protective potential of a novel monoclonal antibody directed against antigenic site B of the hemagglutinin of influenza A viruses. PLoS Pathog 2009; 5(3): e1000350

48. Whittle JRR, Zhang R, Khurana S, King LR, Manischewitz J, Golding H, Dormitzer PR, Haynes BF, Walter EB, Moody MA, Kepler TB, Liao HX, Harrison SC. Broadly neutralizing human antibody that recognizes the receptor-binding pocket of influenza virus hemagglutinin. Proc Natl Acad Sci USA 2011; 108(34): 14216-14221

49. Ekiert DC, Kashyap AK, Steel J, Rubrum A, Bhabha G, Khayat R, Lee JH, Dillon MA, O'Neil RE, Faynboym AM, Horowitz M, Horowitz L, Ward AB, Palese P, Webby R, Lerner RA, Bhatt RR, Wilson IA. Cross-neutralization of influenza A viruses mediated by a single antibody loop. Nature 2012; 489(7417): 526-532

50. Ohshima N, Iba Y, Kubota-Koketsu R, Asano Y, Okuno Y, Kurosawa Y. Naturally occurring antibodies in humans can neutralize a variety of influenza virus strains, including H3, H1, H2, and H5. J Virol 2011; 85(21): 11048-11057
51. Matsuda K, Huang J, Zhou T, Sheng Z, Kang BH, Ishida E, Griesman T, Stuccio S, Bolkhovitinov L, Wohlbold TJ, Chromikova V, Cagigi A, Leung K, Andrews S, Cheung CSF, Pullano AA, Plyler J, Soto C, Zhang B, Yang Y, Joyce MG, Tsybovsky Y, Wheatley A, Narpala SR, Guo Y, Darko S, Bailer RT, Poole A, Liang CJ, Smith J, Alexander J, Gurwith M, Migueles SA, Koup RA, Golding H, Khurana S, McDermott AB, Shapiro L, Krammer F, Kwong PD, Connors M. Prolonged evolution of the memory B cell response induced by a replicating adenovirus-influenza H5 vaccine. Sci Immunol 2019; 4(34): eaau2710

52. Dreyfus C, Laursen NS, Kwaks T, Zuijdgeest D, Khayat R, Ekiert DC, Lee JH, Metlagel Z, Bujny MV, Jongeneelen M, van der Vlugt R, Lamrani M, Korse HJ, Geelen E, Sahin Ö, Sieuwerts M, Brakenhoff JP, Vogels R, Li OT, Poon LL, Peiris M, Koudstaal W, Ward AB, Wilson IA, Goudsmit J, Friesen RH. Highly conserved protective epitopes on influenza B viruses. Science 2012; 337 (6100): 1343-1348

53. Shen C, Chen J, Li R, Zhang M, Wang G, Stegalkina S, Zhang L, Chen J, Cao J, Bi X, Anderson SF, Alefantis T, Zhang M, Cai X, Yang K, Zheng Q, Fang M, Yu H, Luo W, Zheng Z, Yuan Q, Zhang J, Wai-Kuo Shih J, Kleanthous H, Chen H, Chen Y, Xia N. A multimechanistic antibody targeting the receptor binding site potently cross-protects against influenza B viruses. Sci Transl Med 2017; 9(412): eaam5752

54. Dreyfus C, Ekiert DC, Wilson IA. Structure of a classical broadly neutralizing stem antibody in complex with a pandemic $\mathrm{H} 2$ influenza virus hemagglutinin. J Virol 2013; 87(12): 7149-7154

55. Ekiert DC, Bhabha G, Elsliger MA, Friesen RH, Jongeneelen M, Throsby M, Goudsmit J, Wilson IA. Antibody recognition of a highly conserved influenza virus epitope. Science 2009; 324 (5924): 246-251

56. Yamayoshi S, Uraki R, Ito M, Kiso M, Nakatsu S, Yasuhara A, Oishi K, Sasaki T, Ikuta K, Kawaoka Y. A broadly reactive human anti-hemagglutinin stem monoclonal antibody that inhibits influenza A virus particle release. EBioMedicine 2017; 17: 182-191

57. Kallewaard NL, Corti D, Collins PJ, Neu U, McAuliffe JM, Benjamin E, Wachter-Rosati L, Palmer-Hill FJ, Yuan AQ, Walker PA, Vorlaender MK, Bianchi S, Guarino B, De Marco A, Vanzetta F, Agatic G, Foglierini M, Pinna D, Fernandez-Rodriguez B, Fruehwirth A, Silacci C, Ogrodowicz RW, Martin SR, Sallusto F, Suzich JA, Lanzavecchia A, Zhu Q, Gamblin SJ, Skehel JJ. Structure and function analysis of an antibody recognizing all influenza A subtypes. Cell 2016; 166(3): 596-608

58. Sui J, Hwang WC, Perez S, Wei G, Aird D, Chen LM, Santelli E, Stec B, Cadwell G, Ali M, Wan H, Murakami A, Yammanuru A, Han T, Cox NJ, Bankston LA, Donis RO, Liddington RC, Marasco WA. Structural and functional bases for broad-spectrum neutralization of avian and human influenza A viruses. Nat Struct Mol Biol 2009; 16(3): 265-273

59. Ledgerwood JE, Wei CJ, Hu Z, Gordon IJ, Enama ME, Hendel CS, McTamney PM, Pearce MB, Yassine HM, Boyington JC, Bailer R, Tumpey TM, Koup RA, Mascola JR, Nabel GJ, Graham BS; VRC 306 Study Team. DNA priming and influenza vaccine immunogenicity: two phase 1 open label randomised clinical trials. Lancet Infect Dis 2011; 11(12): 916-924

60. Wheatley AK, Whittle JR, Lingwood D, Kanekiyo M, Yassine HM, Ma SS, Narpala SR, Prabhakaran MS, Matus-Nicodemos RA, 
Bailer RT, Nabel GJ, Graham BS, Ledgerwood JE, Koup RA, McDermott AB. H5N1 vaccine-elicited memory B cells are genetically constrained by the IGHV locus in the recognition of a neutralizing epitope in the hemagglutinin stem. J Immunol 2015; 195(2): 602-610

61. Whittle JRR, Wheatley AK, Wu L, Lingwood D, Kanekiyo M, Ma SS, Narpala SR, Yassine HM, Frank GM, Yewdell JW, Ledgerwood JE, Wei CJ, McDermott AB, Graham BS, Koup RA, Nabel GJ. Flow cytometry reveals that H5N1 vaccination elicits crossreactive stem-directed antibodies from multiple Ig heavy-chain lineages. J Virol 2014; 88(8): 4047-4057

62. Sui J, Hwang WC, Perez S, Wei G, Aird D, Chen LM, Santelli E, Stec B, Cadwell G, Ali M, Wan H, Murakami A, Yammanuru A, Han T, Cox NJ, Bankston LA, Donis RO, Liddington RC, Marasco WA. Structural and functional bases for broad-spectrum neutralization of avian and human influenza A viruses. Nat Struct Mol Biol 2009; 16(3): 265-273

63. Dreyfus C, Laursen NS, Kwaks T, Zuijdgeest D, Khayat R, Ekiert DC, Lee JH, Metlagel Z, Bujny MV, Jongeneelen M, van der Vlugt R, Lamrani M, Korse HJ, Geelen E, Sahin Ö, Sieuwerts M, Brakenhoff JP, Vogels R, Li OT, Poon LL, Peiris M, Koudstaal W, Ward AB, Wilson IA, Goudsmit J, Friesen RH. Highly conserved protective epitopes on influenza B viruses. Science 2012; 337 (6100): 1343-1348

64. Ekiert DC, Friesen RH, Bhabha G, Kwaks T, Jongeneelen M, Yu W, Ophorst C, Cox F, Korse HJ, Brandenburg B, Vogels R, Brakenhoff JP, Kompier R, Koldijk MH, Cornelissen LA, Poon LL, Peiris M, Koudstaal W, Wilson IA, Goudsmit J. A highly conserved neutralizing epitope on group 2 influenza A viruses. Science 2011; 333(6044): 843-850

65. Corti D, Voss J, Gamblin SJ, Codoni G, Macagno A, Jarrossay D, Vachieri SG, Pinna D, Minola A, Vanzetta F, Silacci C, FernandezRodriguez BM, Agatic G, Bianchi S, Giacchetto-Sasselli I, Calder L, Sallusto F, Collins P, Haire LF, Temperton N, Langedijk JP, Skehel JJ, Lanzavecchia A. A neutralizing antibody selected from plasma cells that binds to group 1 and group 2 influenza A hemagglutinins. Science 2011; 333(6044): 850-856

66. DiLillo DJ, Tan GS, Palese P, Ravetch JV. Broadly neutralizing hemagglutinin stalk-specific antibodies require $\mathrm{Fc} \gamma \mathrm{R}$ interactions for protection against influenza virus in vivo. Nat Med 2014; 20(2): 143-151

67. Krammer F, Palese P. Advances in the development of influenza virus vaccines. Nat Rev Drug Discov 2015; 14(3): 167-182

68. Lee PS, Wilson IA. Structural characterization of viral epitopes recognized by broadly cross-reactive antibodies. Curr Top Microbiol Immunol 2015; 386: 323-341

69. Seok JH, Kim J, Lee DB, Cho KJ, Lee JH, Bae G, Chung MS, Kim $\mathrm{KH}$. Conformational modulation of influenza virus hemagglutinin: characterization and in vivo efficacy of monomeric form. Sci Rep 2017; 7(1): 7540

70. Angeletti D, Kosik I, Santos JJS, Yewdell WT, Boudreau CM, Mallajosyula VVA, Mankowski MC, Chambers M, Prabhakaran M, Hickman HD, McDermott AB, Alter G, Chaudhuri J, Yewdell JW. Outflanking immunodominance to target subdominant broadly neutralizing epitopes. Proc Natl Acad Sci USA 2019; 116(27): 13474-13479

71. Krammer F, Palese P. Advances in the development of influenza virus vaccines. Nat Rev Drug Discov 2015; 14(3): 167-182

72. Raymond DD, Bajic G, Ferdman J, Suphaphiphat P, Settembre EC, Moody MA, Schmidt AG, Harrison SC. Conserved epitope on influenza-virus hemagglutinin head defined by a vaccine-induced antibody. Proc Natl Acad Sci USA 2018; 115(1): 168-173

73. Correia BE, Bates JT, Loomis RJ, Baneyx G, Carrico C, Jardine JG, Rupert P, Correnti C, Kalyuzhniy O, Vittal V, Connell MJ, Stevens E, Schroeter A, Chen M, Macpherson S, Serra AM, Adachi Y, Holmes MA, Li Y, Klevit RE, Graham BS, Wyatt RT, Baker D, Strong RK, Crowe JE Jr1, Johnson PR, Schief WR. Proof of principle for epitope-focused vaccine design. Nature 2014; 507 (7491): 201-206

74. Haynes BF, Kelsoe G, Harrison SC, Kepler TB. B-cell-lineage immunogen design in vaccine development with HIV-1 as a case study. Nat Biotechnol 2012; 30(5): 423-433

75. Mascola JR, Haynes BF. HIV-1 neutralizing antibodies: understanding nature's pathways. Immunol Rev 2013; 254(1): 225-244

76. Bajic G, Maron MJ, Adachi Y, Onodera T, McCarthy KR, McGee CE, Sempowski GD, Takahashi Y, Kelsoe G, Kuraoka M, Schmidt AG. Influenza antigen engineering focuses immune responses to a subdominant but broadly protective viral epitope. Cell Host Microbe 2019; 25(6): 827-835.e6

77. Lavie M, Hanoulle X, Dubuisson J. Glycan shielding and modulation of hepatitis $\mathrm{C}$ virus neutralizing antibodies. Front Immunol 2018; 9: 910

78. Watanabe Y, Raghwani J, Allen JD, Seabright GE, Li S, Moser F, Huiskonen JT, Strecker T, Bowden TA, Crispin M. Structure of the Lassa virus glycan shield provides a model for immunological resistance. Proc Natl Acad Sci USA 2018; 115(28): 7320-7325

79. Hervé PL, Lorin V, Jouvion G, Da Costa B, Escriou N. Addition of $\mathrm{N}$-glycosylation sites on the globular head of the $\mathrm{H} 5$ hemagglutinin induces the escape of highly pathogenic avian influenza A H5N1 viruses from vaccine-induced immunity. Virology 2015; 486: 134 145

80. Liu WC, Jan JT, Huang YJ, Chen TH, Wu SC. Unmasking stemspecific neutralizing epitopes by abolishing N-linked glycosylation sites of influenza virus hemagglutinin proteins for vaccine design. $\mathrm{J}$ Virol 2016; 90(19): 8496-8508

81. Florek NW, Weinfurter JT, Jegaskanda S, Brewoo JN, Powell TD, Young GR, Das SC, Hatta M, Broman KW, Hungnes O, Dudman SG, Kawaoka Y, Kent SJ, Stinchcomb DT, Osorio JE, Friedrich TC. Modified vaccinia virus Ankara encoding influenza virus hemagglutinin induces heterosubtypic immunity in macaques. J Virol 2014; 88(22): 13418-13428

82. Kamlangdee A, Kingstad-Bakke B, Anderson TK, Goldberg TL, Osorio JE. Broad protection against avian influenza virus by using a modified vaccinia Ankara virus expressing a mosaic hemagglutinin gene. J Virol 2014; 88(22): 13300-13309

83. Yewdell JW, Taylor A, Yellen A, Caton A, Gerhard W, Bächi T. Mutations in or near the fusion peptide of the influenza virus hemagglutinin affect an antigenic site in the globular region. J Virol 1993; 67(2): 933-942

84. Yewdell JW, Yellen A, Bächi T. Monoclonal antibodies localize events in the folding, assembly, and intracellular transport of the influenza virus hemagglutinin glycoprotein. Cell 1988; 52(6): 843852

85. Yewdell JW, Gerhard W, Bachi T. Monoclonal anti-hemagglutinin 
antibodies detect irreversible antigenic alterations that coincide with the acid activation of influenza virus A/PR/834-mediated hemolysis. J Virol 1983; 48(1): 239-248

86. Lee J, Boutz DR, Chromikova V, Joyce MG, Vollmers C, Leung K, Horton AP, DeKosky BJ, Lee CH, Lavinder JJ, Murrin EM, Chrysostomou C, Hoi KH, Tsybovsky Y, Thomas PV, Druz A, Zhang B, Zhang Y, Wang L, Kong WP, Park D, Popova LI, Dekker CL, Davis MM, Carter CE, Ross TM, Ellington AD, Wilson PC, Marcotte EM, Mascola JR, Ippolito GC, Krammer F, Quake SR, Kwong PD, Georgiou G. Molecular-level analysis of the serum antibody repertoire in young adults before and after seasonal influenza vaccination. Nat Med 2016; 22(12): 1456-1464

87. Bangaru S, Lang S, Schotsaert M, Vanderven HA, Zhu X, Kose N, Bombardi R, Finn JA, Kent SJ, Gilchuk P, Gilchuk I, Turner HL, García-Sastre A, Li S, Ward AB, Wilson IA, Crowe JE Jr. A site of vulnerability on the influenza virus hemagglutinin head domain trimer interface. Cell 2019; 177(5): 1136-1152.e18

88. Das DK, Govindan R, Nikić-Spiegel I, Krammer F, Lemke EA, Munro JB. Direct visualization of the conformational dynamics of single influenza hemagglutinin trimers. Cell 2018; 174(4): 926937.e12

89. Garcia NK, Lee KK. Dynamic viral glycoprotein machines: approaches for probing transient states that drive membrane fusion. Viruses 2016; 8(1): E15

90. Puchades C, Kükrer B, Diefenbach O, Sneekes-Vriese E, Juraszek J, Koudstaal W, Apetri A. Epitope mapping of diverse influenza hemagglutinin drug candidates using HDX-MS. Sci Rep 2019; 9 (1): 4735

91. Copeland CS, Doms RW, Bolzau EM, Webster RG, Helenius A. Assembly of influenza hemagglutinin trimers and its role in intracellular transport. J Cell Biol 1986; 103(4): 1179-1191

92. Gething MJ, McCammon K, Sambrook J. Expression of wild-type and mutant forms of influenza hemagglutinin: the role of folding in intracellular transport. Cell 1986; 46(6): 939-950

93. Chen J, Lee KH, Steinhauer DA, Stevens DJ, Skehel JJ, Wiley DC. Structure of the hemagglutinin precursor cleavage site, a determinant of influenza pathogenicity and the origin of the labile conformation. Cell 1998; 95(3): 409-417

94. Steinhauer DA. Role of hemagglutinin cleavage for the pathogenicity of influenza virus. Virology 1999; 258(1): 1-20

95. Suzuki K, Grigorova I, Phan TG, Kelly LM, Cyster JG. Visualizing
B cell capture of cognate antigen from follicular dendritic cells. J Exp Med 2009; 206(7): 1485-1493

96. Heesters BA, Chatterjee P, Kim YA, Gonzalez SF, Kuligowski MP, Kirchhausen T, Carroll MC. Endocytosis and recycling of immune complexes by follicular dendritic cells enhances B cell antigen binding and activation. Immunity 2013; 38(6): 1164-1175

97. Pincetic A, Bournazos S, DiLillo DJ, Maamary J, Wang TT, Dahan R, Fiebiger BM, Ravetch JV. Type I and type II Fc receptors regulate innate and adaptive immunity. Nat Immunol 2014; 15(8): 707-716

98. Bohn AB, Nederby L, Harbo T, Skovbo A, Vorup-Jensen T, Krog J, Jakobsen J, Hokland ME. The effect of IgG levels on the number of natural killer cells and their Fc receptors in chronic inflammatory demyelinating polyradiculoneuropathy. Eur J Neurol 2011; 18(6): 919-924

99. Nimmerjahn F. Fc-receptors and innate immune effector cells involved in IgG activity. Immunology 2011; 135: 19

100. Munro JB, Lee KK. Probing structural variation and dynamics in the HIV-1 Env fusion glycoprotein. Curr HIV Res 2018; 16(1): 512

101. Rey FA, Stiasny K, Vaney MC, Dellarole M, Heinz FX. The bright and the dark side of human antibody responses to flaviviruses: lessons for vaccine design. EMBO Rep 2018; 19(2): 206-224

102. Yuan Y, Cao D, Zhang Y, Ma J, Qi J, Wang Q, Lu G, Wu Y, Yan J, Shi Y, Zhang X, Gao GF. Cryo-EM structures of MERS-CoV and SARS-CoV spike glycoproteins reveal the dynamic receptor binding domains. Nat Commun 2017; 8(1): 15092

103. Wu Y, Li S, Du L, Wang C, Zou P, Hong B, Yuan M, Ren X, Tai W, Kong Y, Zhou C, Lu L, Zhou X, Jiang S, Ying T. Neutralization of Zika virus by germline-like human monoclonal antibodies targeting cryptic epitopes on envelope domain III. Emerg Microbes Infect 2017; 6(10): e89

104. Miller LH, Ackerman HC, Su XZ, Wellems TE. Malaria biology and disease pathogenesis: insights for new treatments. Nat Med 2013; 19(2): 156-167

105. Mozdzanowska K, Feng J, Gerhard W. Virus-neutralizing activity mediated by the Fab fragment of a hemagglutinin-specific antibody is sufficient for the resolution of influenza virus infection in SCID mice. J Virol 2003; 77(15): 8322-8328

106. Wu Y, Jiang S, Ying T. Single-domain antibodies as therapeutics against human viral diseases. Front Immunol 2017; 8: 1802 